\title{
Re-evaluation of temperature at the updip limit of locked portion of Nankai megasplay inferred from IODP Site C0002 temperature observatory
}

Takamitsu Sugihara ${ }^{1 *}$, Masataka Kinoshita ${ }^{2}$, Eichiro Araki ${ }^{3}$, Toshinori Kimura ${ }^{3}$, Masanori Kyo ${ }^{1}$, Yasuhiro Namba ${ }^{1}$, Yukari Kido ${ }^{1}$, Yoshinori Sanada ${ }^{1}$ and Moe Kyaw Thu ${ }^{1}$

\begin{abstract}
In 2010, the first long-term borehole monitoring system was deployed at approximately $900 \mathrm{~m}$ below the sea floor (mbsf) and was assumed to be situated above the updip limit of the seismogenic zone in the Nankai Trough off Kumano (Site C0002). Four temperature records show that the effect of drilling diminished in less than 2 years. Based on in situ temperatures and thermal conductivities measured on core samples, the temperature measurements and heat flow at $900 \mathrm{mbsf}$ are estimated to be $37.9^{\circ} \mathrm{C}$ and $56 \pm 1 \mathrm{~mW} / \mathrm{m}^{2}$, respectively. This heat flow value is in excellent agreement with that from the shallow borehole temperature corrected for rapid sedimentation in the Kumano Basin. We use these values in the present study to extrapolate the temperature below $900 \mathrm{mbsf}$ for a megasplay fault at approximately 5,200 mbsf and a plate boundary fault at approximately 7,000 mbsf. To extrapolate the temperature downward, we use logging-while-drilling (LWD) bit resistivity data as a proxy for porosity and estimate thermal conductivity from this porosity using a geometrical mean model. The one-dimensional (1-D) thermal conduction model used for the extrapolation includes radioactive heat and frictional heat production at the plate boundary fault. The estimated temperature at the megasplay ranges from $132^{\circ} \mathrm{C}$ to $149^{\circ} \mathrm{C}$, depending on the assumed thermal conductivity and radioactive heat production values. These values are significantly higher, by up to $40^{\circ} \mathrm{C}$, than some of previous two-dimensional (2-D) numerical model predictions that can account for the high heat flow seaward of the deformation front, including a hydrothermal circulation within the subducted igneous oceanic crust. However, our results are in good agreement with those of the 2-D model, which does not include the advection cooling effect. The results imply that 2-D geometrical effects as well as the influence of the advective cooling may be critical and should be evaluated more quantitatively. Revision of 2-D simulation by introducing our new boundary conditions $\left(37.9^{\circ} \mathrm{C}\right.$ of in situ temperature at $900 \mathrm{mbsf}$ and approximately $56 \mathrm{~mW} / \mathrm{m}^{2}$ heat flow) will be essential. Ultimately, in situ temperature measurements at the megasplay fault are required to understand seismogenesis in the Nankai subduction zone.
\end{abstract}

Keywords: Seismogenic zone; Scientific drilling; Nankai Trough; Thermal regime; Heat flow; Thermal conductivity; Logging while drilling; Long-term bore hole observatory; Integrated Ocean Drilling Program (IODP)

\section{Background}

The Nankai Trough is a convergent plate boundary where megathrust earthquakes $\left(M_{\mathrm{w}}>8\right)$ have repeatedly occurred. In order to understand the nature of the seismogenic zone associated with the subduction of the Shikoku Basin along the Nankai Trough, the Nankai Trough Seismogenic Zone

\footnotetext{
* Correspondence: sugiharat@jamstec.go.jp

${ }^{1}$ Center for Deep Earth Exploration, Japan Agency for Marine-Earth Science and Technology, 3173-25 Showa-machi, Kanazawa-ku, Yokohama 236-0001, Japan

Full list of author information is available at the end of the article
}

Experiment (NanTroSEIZE) is being conducted across the Nankai Trough off Kii Peninsula (Kinoshita et al. 2009; Saffer et al. 2010; Saito et al. 2010; Kopf et al. 2011; Henry et al. 2012; Moore et al. 2013) as a Complex Drilling Project of the Integrated Ocean Drilling Program (IODP).

Temperature is one of the key state parameters controlling the seismogenic behavior of the plate boundary fault zones (e.g., Hyndman et al. 1995; Moore and Saffer 2001). Therefore, in situ measurement of the formation temperature is one of the important scientific tasks of the experiment (e.g., Tobin and Kinoshita 2006; 


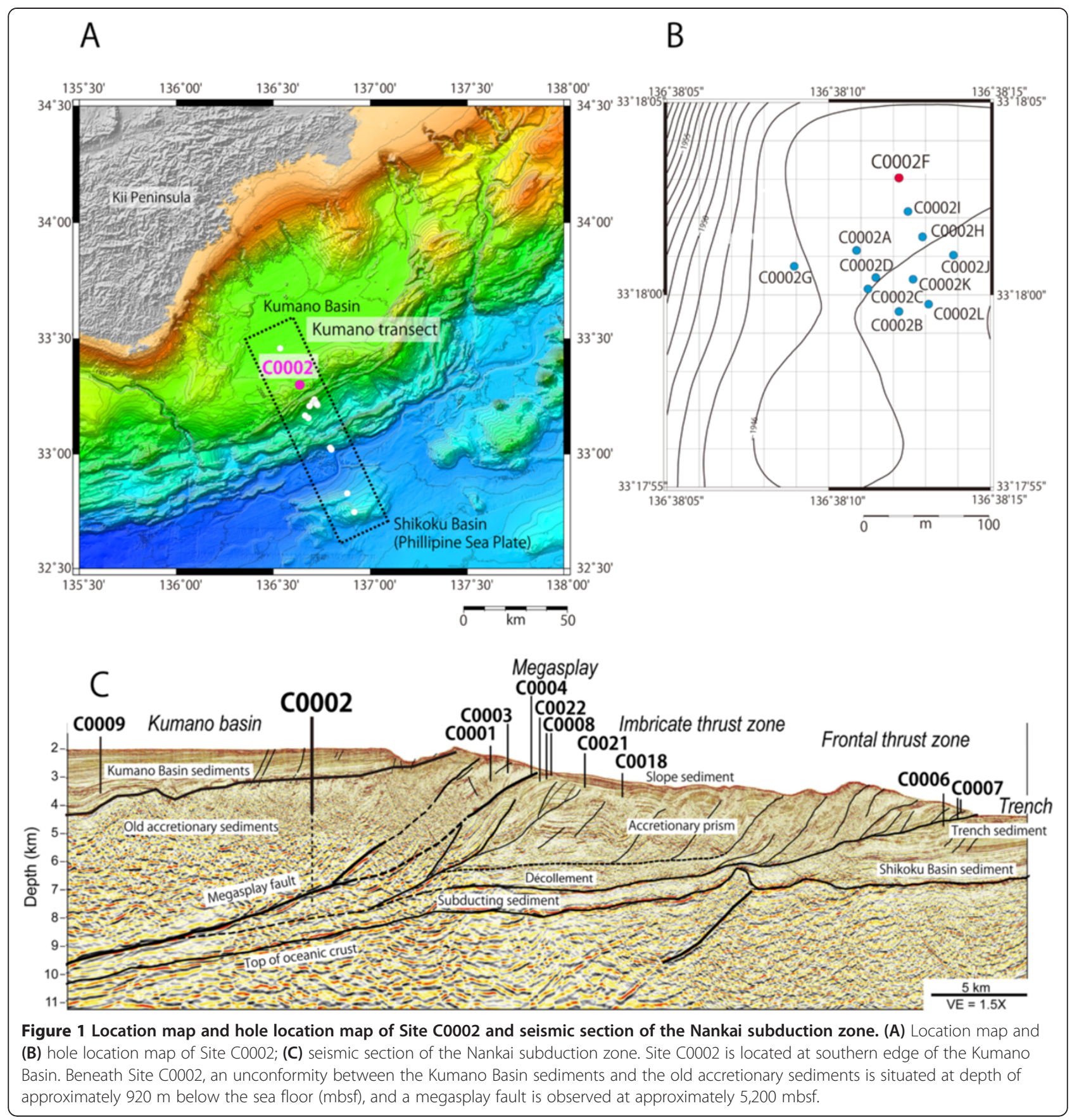

Harris et al. 2013). IODP NanTroSEIZE Site C0002 (Figure 1A), located near the seaward edge of the Kumano Forearc Basin, is planned to be a deep drilling riser site for penetrating the megasplay fault and the plate boundary megathrust. The megasplay fault is a long thrust fault that rises from the plate boundary megathrust and intersects the sea floor at the landward edge of the accretionary prism (e.g., Park et al. 2002; Tobin and Kinoshita 2006; Park and Kodaira 2012). Operations at Site C0002 are summarized in Table 1. Hole C0002F was drilled to
2,005.5 $\mathrm{m}$ below the sea floor (mbsf) during IODP Expedition 338 (Moore et al. 2013) and was deepened to approximately 3,000 mbsf during Expedition 348 (Expedition 348 Scientists in preparation).

Formation temperature measurements have been conducted at shallow depths (approximately $180 \mathrm{mbsf}$ ) by using the third-generation Advanced Piston Corer Temperature (APCT-3) tool (Heesemann et al. 2006) in Holes C0002C and C0002D during Expedition 315, and the temperature-depth profile beneath Site C0002 was 
Table 1 Summary of operation in site $\mathrm{C0002}$

\begin{tabular}{|c|c|c|c|c|c|c|c|c|}
\hline $\begin{array}{l}\text { Hole } \\
\text { ID }\end{array}$ & Expedition & Operation date & Operation & $\begin{array}{l}\text { Water } \\
\text { depth } \\
\text { (mMSL) }\end{array}$ & $\begin{array}{l}\text { Total } \\
\text { depth } \\
\text { (mbsf) }\end{array}$ & $\begin{array}{c}\text { LWD } \\
\text { interval } \\
\text { (mbsf) }\end{array}$ & $\begin{array}{c}\text { Coring } \\
\text { interval } \\
\text { (mbsf) }\end{array}$ & Remarks \\
\hline C0002A & 314 & September 21 to November 15, 2007 & LWD & $1,936.0$ & $1,401.5$ & $\begin{array}{l}0.0 \text { to } \\
1401.5\end{array}$ & - & \\
\hline C0002B & 315 & November 16 to December, 2007 & Coring & $1,937.5$ & $1,057.0$ & - & $\begin{array}{l}475.0 \text { to } \\
1,057.0\end{array}$ & RCB coring \\
\hline C0002C & 315 & November 16 to December, 2007 & Coring & $1,936.6$ & 13.8 & - & 0.0 to 13.8 & HPCS coring with APCT-3 \\
\hline C0002D & 315 & November 16 to December, 2007 & Coring & $1,937.1$ & 204.0 & - & $\begin{array}{l}0.0 \text { to } \\
204.0\end{array}$ & HPCS coring with APCT-3 \\
\hline C0002E & 326 & July 15 to August 29, 2010 & - & - & - & - & - & Failed to spud-in \\
\hline $\mathrm{COOO2F}$ & 326,338 & $\begin{array}{l}\text { July } 15 \text { to August 20, 2010; October 1, } \\
2012 \text { to January 13, } 2013\end{array}$ & $\begin{array}{l}\text { LWD/mud } \\
\text { logging }\end{array}$ & $1,939.0$ & $2,000.5^{a}$ & $\begin{array}{l}875.5 \text { to } \\
2000.5\end{array}$ & - & $\begin{array}{l}\text { Deep riser hole (planned } \\
\text { TD 5,200 mbsf) }\end{array}$ \\
\hline C0002G & 332 & October 25 to December 11, 2010 & $\begin{array}{l}\text { LWD/ } \\
\text { observatory }\end{array}$ & $1,936.0$ & 980.0 & $\begin{array}{l}0.0 \text { to } \\
980.0\end{array}$ & - & LTBMS $^{\mathrm{b}}$ was installed. \\
\hline $\mathrm{COOO2H}$ & 338 & October 1, 2012 to January 13, 2013 & Coring & $1,936.5$ & $1,120.0$ & - & $\begin{array}{c}1,100.5 \text { to } \\
1,120.0\end{array}$ & RCB coring \\
\hline C0002I & 338 & October 1, 2012 to January 13, 2013 & Coring & $1,936.0$ & - & - & - & $\begin{array}{l}\text { Stuck drill pipe before } \\
\text { coring }\end{array}$ \\
\hline C0002J & 338 & October 1, 2012 to January 13, 2013 & Coring & $1,937.5$ & 940.0 & - & $\begin{array}{l}902.0 \text { to } \\
940.0\end{array}$ & RCB coring \\
\hline C0002K & 338 & October 1, 2012 to January 13, 2013 & Coring & $1,937.5$ & 286.5 & - & $\begin{array}{l}200 \text { to } \\
286.5\end{array}$ & HPCS and ESCS coring \\
\hline C0002L & 338 & October 1, 2012 to January 13, 2013 & Coring & $1,937.5$ & 505.0 & - & $\begin{array}{c}277.0 \text { to } \\
505.0\end{array}$ & ESCS coring \\
\hline
\end{tabular}

${ }^{a}$ Current depth (August 2013). ${ }^{b}$ LTBMS, long-term borehole monitoring system.

predicted based on these measurements (Ashi et al. 2009). Although this tool is useful for determining formation temperature undisturbed by drilling, it relies on the softness of the sediment at the bottom of the borehole being drilled to allow the thin thermal probe to penetrate smoothly without creating cracks or gaps between the probe and the formation. As such, it is applicable to subbottom depths of 100 to $200 \mathrm{~m}$ only. Temperatures at deeper depths must be extrapolated from repeated temperature logs or measured through a long-term observatory system.

During Expedition 332, conducted in November to December 2010, the first long-term borehole monitoring system (LTBMS) was successfully installed to a depth of about 930 mbsf in Hole C0002G (Kopf et al. 2011). The LTBMS contains sensors for volume strain, broadband, and high-frequency seismic waves, tilt, pore pressure, and temperature. In addition, five thermistors were placed along a 150-m-long string (Expedition 332 Scientists 2011a,b; Kimura et al. 2013). In January 2013, the LTBMS was connected to the Dense Ocean Floor Network System for Earthquakes and Tsunamis (DONET), which is a submarine cabled real-time seafloor observatory network for earthquake and tsunami monitoring (Kitada et al. 2013). This connection enabled real-time acquisition of the LTBMS data. Prior to the connection with the DONET, data stored in the LTBMS was recovered using a remotely operated vehicle (ROV) in December 2010 just after the installation and in August 2011.

In this paper, we show the in situ temperature and heat flow at the lithological boundary between the Kumano Basin and the underlying old accretionary prism, determined from the LTBMS temperatures and the thermal conductivity values measured on core samples. We then extrapolate the temperature profile beneath Site C0002 down to the plate boundary fault assuming a steady-state, one-dimensional (1-D) thermal conduction regime including radioactive and frictional heat production, with the thermal conductivity curve inferred from log resistivity. The results are compared with profiles estimated by previous studies.

\section{Methods}

\section{Geological setting around Site $\mathrm{COOO2}$}

Based on multichannel seismic (MCS) reflection surveys in the area off Kii Peninsula, Park et al. (2002) and Moore et al. (2009) indicated the existence of a megasplay fault (approximately 5,200 mbsf) including landward-dipping thrust faults branching upward from the plate interface (Figure 1). This megasplay fault reaches the seafloor just seaward of the outer ridge. 


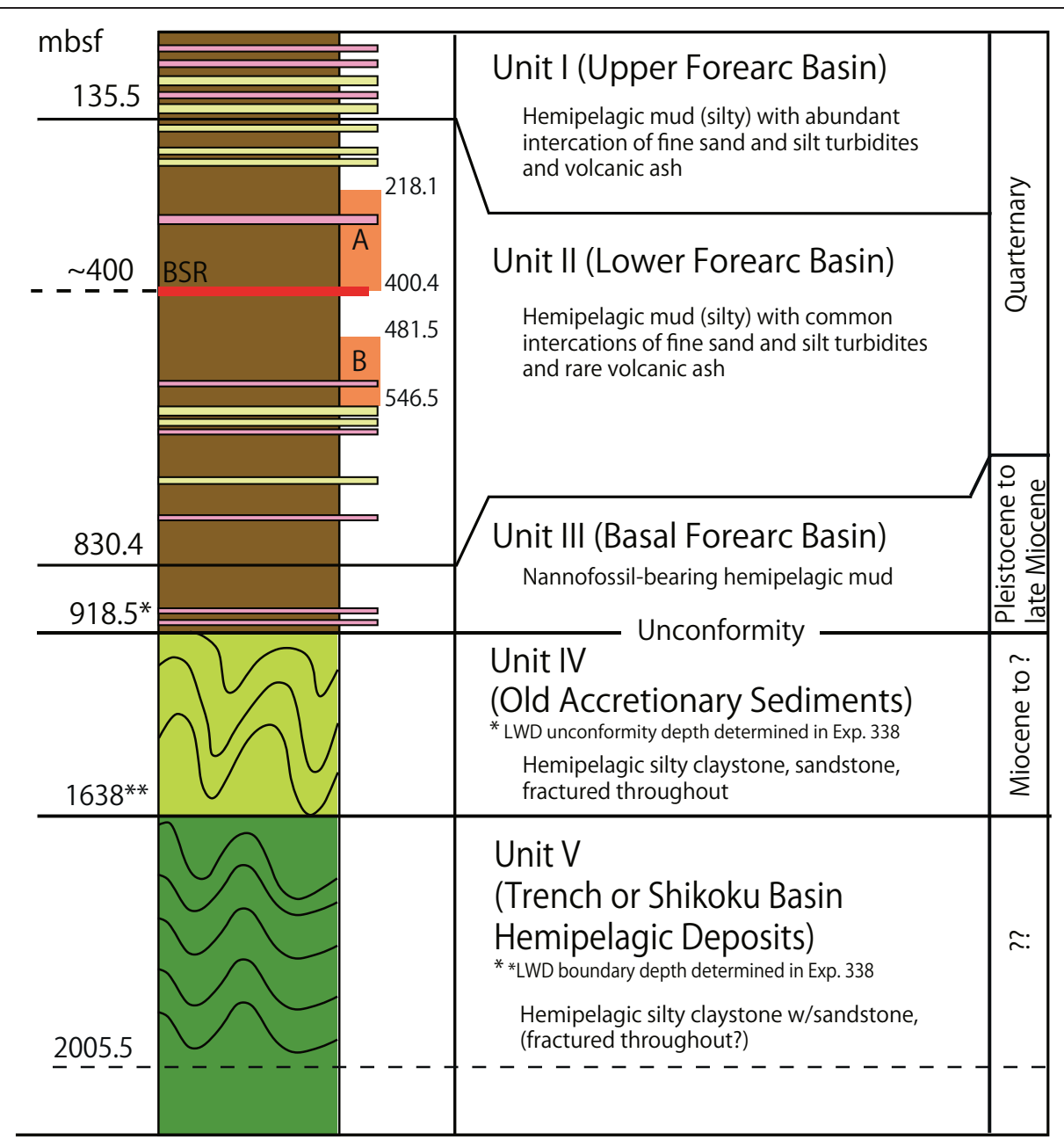

Figure 2 Schematic geological column beneath Site C0002. Lithological characteristics of Units IV and V to 2,005.5 meters below the sea floor (mbsf) were well defined in Expedition 338 (Moore et al. 2013).

On the basis of interpretation of the MCS profiles (Moore et al. 2009) and the drilling results to 2,005.5 mbsf, the sedimentary sequence beneath Site C0002 was divided into five geological units (Expedition 314 Scientists 2009; Moore et al. 2013). The lithological characteristics at each unit beneath Site $\mathrm{C0002}$ are shown in Figure 2. Units I to III constitute Kumano Basin sediments, whereas Units IV and V belong to the old accretionary sediments.

Units I to III are composed mainly of hemipelagic mud frequently interbedded by fine sand and silt turbidities and are interpreted as forearc sediments formed on the southern distal basin plane of the Kumano Basin. The boundary between Units III and IV is defined by a sharp change in structural style at depths of 900 to 950 mbsf and is interpreted as an unconformity at 918.5 mbsf (C0002F; logging while drilling (LWD)) to 935.6 mbsf (C0002A; LWD) (Kinoshita et al. 2009; Moore et al. 2013).
Unit IV is composed mainly of noncalcareous silty claystone to clayey siltstone with interbedded sandstones, whereas Unit $\mathrm{V}$ is composed almost entirely of silty claystone without subordinate sandstone. The boundary between Units IV and V at 1,638 mbsf was determined by the LWD data obtained during Expedition 338 (Moore et al. 2013) and is considered to be a small fault. Based on the lithological characteristics of Units IV and V, Unit IV was interpreted as accretionary prism sediments that accumulated in either a paleo-trench or the Shikoku Basin, and Unit V is considered to be a thick layer of hemipelagic sediments that was deposited in the Shikoku Basin before subducting at the Nankai Trough (Moore et al. 2013).

\section{Dataset for estimation of temperature profile In situ temperature}

The configuration of thermistors along the thermistor string is shown in Figure 3. T1 through T3 are inside the 


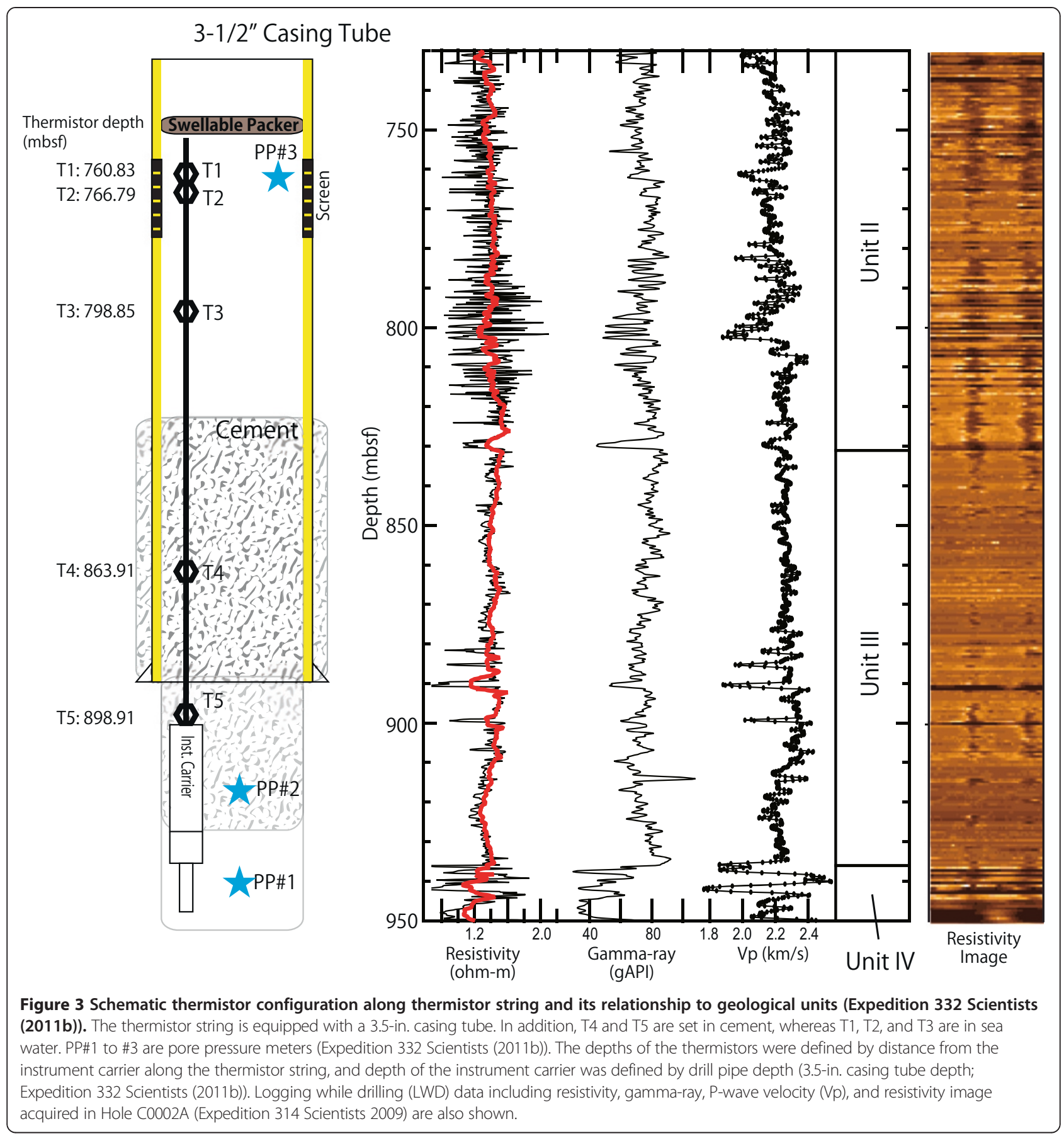

casing sealed by the packer on its top and by cement on its bottom. The uppermost thermistors (T1 and T2) are located at the screen interval with the pore pressure port. $\mathrm{T} 4$ and $\mathrm{T} 5$ are installed within the cement, and T5 is located just below the casing bottom.

The thermistors in the LTBMS were calibrated using the Steinhart-Hart equation (Steinhart and Hart 1968) for a temperature range of $5^{\circ} \mathrm{C}$ to $45^{\circ} \mathrm{C}$ prior to installation. Details on the calibration have been described by
Expedition 332 Scientists (2011a) and Kimura et al. (2013). The uncertainty in the temperatures from the thermistors is estimated to be less than $20 \mathrm{mK}$ except for T1. The uncertainty for T1 is estimated to be approximately $100 \mathrm{mK}$.

The LTBMS was installed into Hole C0002G on December 8, 2010, during Expedition 332. A connection test using an ROV and data download for a sensor health-check in the LTBMS were conducted soon after 
Table 2 Summary of temperature data acquired by long-term borehole monitoring system (LTBMS)

\begin{tabular}{cccccc}
\hline $\begin{array}{c}\text { Thermistor } \\
\text { No. }\end{array}$ & $\begin{array}{c}\text { Depth } \\
\left(\begin{array}{c}\text { mbsf) } \\
\mathbf{a}\end{array}\right.\end{array}$ & $\begin{array}{c}\text { Exp.332 }\left({ }^{\circ} \mathrm{C}\right) \\
\text { December 8, 2010 }\end{array}$ & $\begin{array}{c}\text { KY11-09 }\left({ }^{\circ} \mathbf{C}\right) \\
\text { August 1, 2011 }\end{array}$ & $\begin{array}{c}\text { KY13-02 }\left({ }^{\circ} \mathrm{C}\right) \\
\text { January 24, 2013 (via DONET) }\end{array}$ & $\begin{array}{c}\text { Difference between KY1302 and } \\
\text { Exp.332 }\left({ }^{\circ} \mathrm{C}\right)\end{array}$ \\
\hline T1 & 760.83 & 29.38 & 33.84 & 33.99 & 4.61 \\
T2 & 766.79 & 29.55 & 32.67 & 32.94 & 3.39 \\
T3 & 798.85 & 30.33 & 33.88 & 34.06 & 3.73 \\
T4 & 863.91 & 32.96 & 36.34 & 36.45 & 3.49 \\
T5 & 898.91 & 34.34 & 37.91 & 37.89 & 3.55 \\
\hline
\end{tabular}

Depth of each thermistor is after Expedition 332 Scientists (2011b).

the installation. On August 1, 2011, ROV Hyper Dolphin dove to acquire data from the LTBMS during the KY11-09 cruise using R/V Kaiyo, and temperature data for about $1 \mathrm{~h}$ during connection with Hyper Dolphin were recovered. On January 24, 2013, the LTBMS was connected with the DONET, and data have been recovered via the DONET since then.

Temperature data recovered from the thermistor string in the LTBMS are shown in Table 2 and in Figures 4 and 5. The data of the second (August 2011) and third (January 2013) data recovery missions shown in Table 2 are averages for approximately $1 \mathrm{~h}$ from the start of data acquisition. For data recovered after the connection with the DONET, average values for a few days were almost the same as the average data values for $1 \mathrm{~h}$, as shown in Figure 4. The shallowest sensor (T1) showed anomalous values. The apparent temperature increase between the first (December 8, 2010) and second (August 1, 2011) data retrieval periods, followed by a dramatic decrease, indicates a failure in thermistor and/or electrical circuit after the first data recovery. T3 also shows an irregular trend from the end of January 2013, although it had been working properly in 2010 until that time.

Temperatures just after the installation were lower than those recovered in the second and third periods due to the transient cooling effect of drilling mud circulation. Since temperatures during the second and third recoveries are almost identical, we inferred that the temperature at 760 to $900 \mathrm{mbsf}$ obtained in the second and third recoveries are in thermal equilibrium with the formation (Table 2 and Figure 4). We used the temperature data after the connection with the DONET to estimate heat flow from the old accretionary prism, which is discussed later in this paper.

The in situ temperature at 900 mbsf estimated from shallow formation temperatures measured by APCT-3 and the thermal conductivity profile (Expedition 315 Scientists 2009) is $37.9^{\circ} \mathrm{C}$, which is higher than the previous estimation of approximately $32^{\circ} \mathrm{C}$ (Figure 5 ). The average temperature gradient at depth interval of 760 to 900 mbsf was calculated to be $37.4 \mathrm{mK} / \mathrm{m}$, using data from thermistors $\mathrm{T} 2$ to $\mathrm{T} 5$.

\section{Thermal conductivity}

Core samples to $1,150.0$ mbsf were obtained almost continuously from Holes C0002B, C0002C, C0002D, $\mathrm{C} 0002 \mathrm{H}, \mathrm{C0002J}, \mathrm{C} 0002 \mathrm{~K}$, and $\mathrm{C} 0002 \mathrm{~L}$, except for the depth interval of 1,057.0 to 1,100.5 mbsf (Ashi et al. 2009; Moore et al. 2013).

Thermal conductivities were measured on wholeround core samples for soft sediments and half-cut cores for consolidated sediments with the TeKa TK04 thermal conductivity meter (Blum 1997; Expedition 315 Scientists 2009; Moore et al. 2013). Thermal conductivities were measured in the laboratory onboard Chikyu at approximately $20^{\circ} \mathrm{C}$ and were corrected for in situ temperature in a manner similar to that reported by

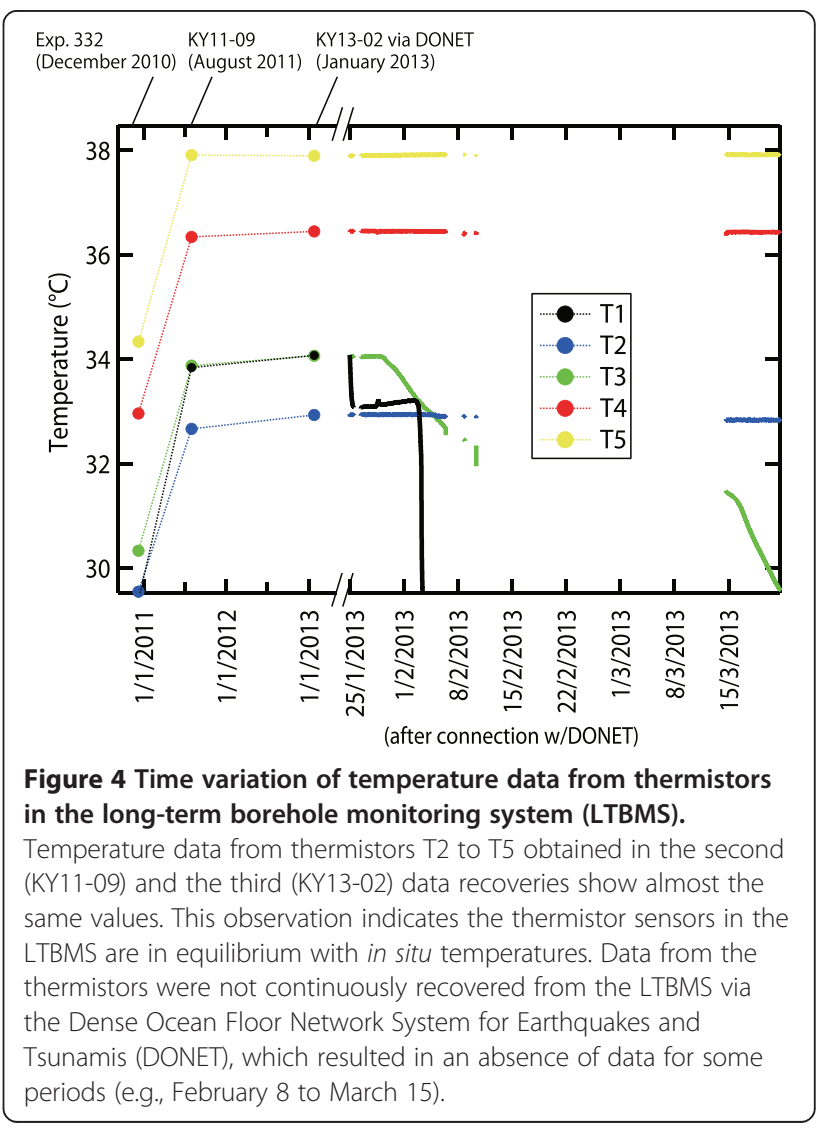




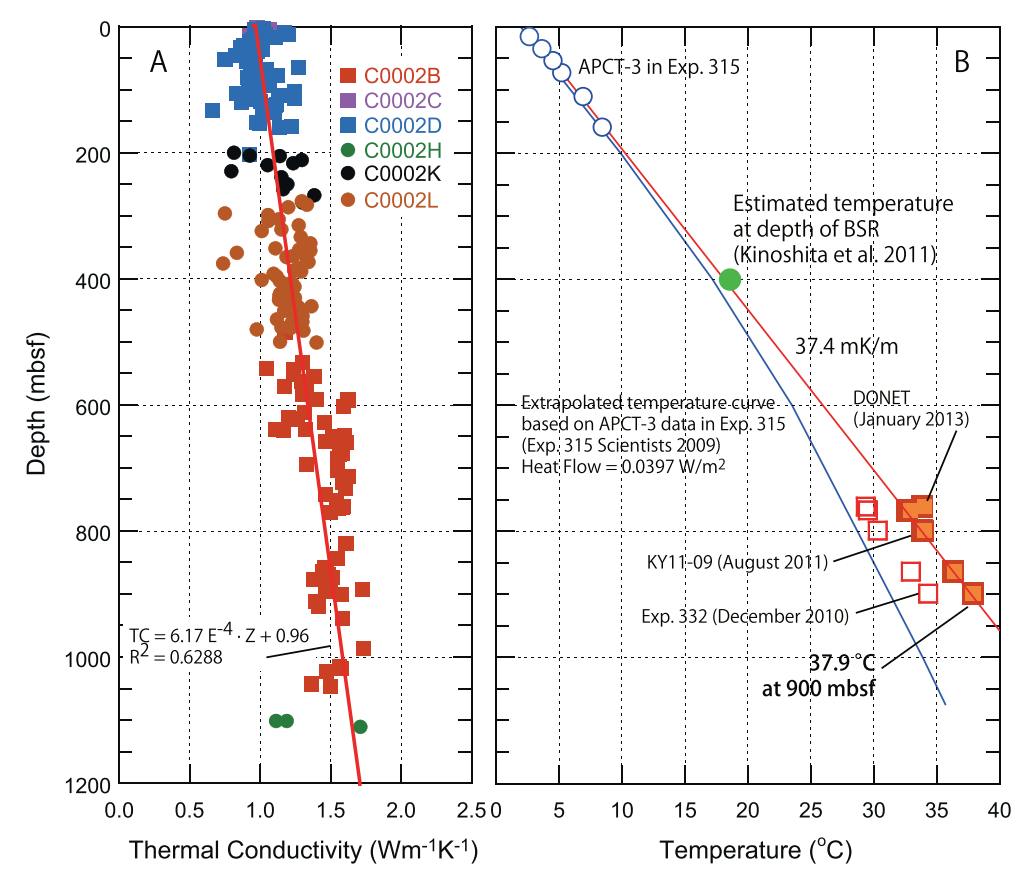

Figure $\mathbf{5}$ In situ temperature data and thermal conductivity. (A) In situ temperature data derived from the long-term borehole monitoring system (LTBMS) and (B) thermal conductivity measured on core samples. The thermal gradient defined by in situ temperature data is obviously higher than that derived from shallower temperature data by using APCT-3. The newly derived thermal gradient is consistent with temperature estimated by methane hydrate phase stability field based on bottom-simulating reflector (BSR) depth in the seismic section (Kinoshita et al. 2011). Thermal conductivity data are linearly correlated with depth. Therefore, the model thermal conductivity can be computed by using linear regression for heat-flow estimation.

Expedition 316 Scientists (2009) and Harris et al. (2011) to determine basal heat flow.

Expedition 316 Scientists (2009) and Harris et al. (2011) estimated errors of both methods by repeated measurement of standard materials and showed that the uncertainty is less than 5\%, as stated by Blum (1997).

Figure 5A shows measured thermal conductivity values with depth. Generally, the values increase with increasing depth, from $1 \mathrm{~W} / \mathrm{m} / \mathrm{K}$ near the seafloor to approximately $1.5 \mathrm{~W} / \mathrm{m} / \mathrm{K}$ at approximately $1,000 \mathrm{mbsf}$.

\section{Heat flow}

The heat flow at the 760 to 900 mbsf interval was estimated using in-situ temperatures and thermal conductivity, as described above. If subseafloor sediment is in a 1-D, steady-state regime, temperature at depth $z$ is defined by the 1-D thermal conduction model (Bullard, 1939):

$$
T_{z}=T_{0}+q_{0} \cdot \sum_{i=1}^{N} \frac{\Delta z_{i}}{k(z)_{i}}
$$

where $T_{0}$ is the temperature at $z=z_{0}$ (760 m here), $q_{0}$ is the heat flux from below, $\Delta z_{i}$ the depth spacing, and $k(\mathrm{z})_{i}$ is the thermal conductivity corresponding at depth $\mathrm{z}$. The term $\Sigma \Delta z_{i} / k(\mathrm{z})_{i}$ is the thermal resistance. We applied a linear regression line to the data of thermal conductivity with depth and used the linear trend to calculate thermal resistance values as a function of $z$.

In situ temperature versus thermal resistance is shown in Figure 6. The heat flow $q_{0}$ is derived as its slope, $56 \pm 1$ $\mathrm{mW} / \mathrm{m}^{2}$, and the uncertainty of estimated heat flow is calculated to be $\pm 1.4 \mathrm{~mW} / \mathrm{m}^{2}$ (approximately $2.5 \%$ relative error) based on the least-square fitting result in Figure 6. The boundary between the Kumano Basin sediments and the old accretionary sediments is located at 918 to 935 mbsf at Site C0002; thus, the estimated heat flow is interpreted as the heat flux passing through the old accretionary sediments, designated as the basal heat flow.

The temperature versus depth profile from the seafloor to $900 \mathrm{mbsf}$ is shown in Figure 5. All temperatures fit in line with its thermal gradient of $37 \mathrm{mK} / \mathrm{m}$, including an estimate from the depth of the BSRs (Kinoshita et al. 2011). This linearity resulted in inconsistent heat flow between shallow $\left(40 \mathrm{~mW} / \mathrm{m}^{2}\right.$; Expedition 315 Scientists 2009) and deep $\left(56 \mathrm{~mW} / \mathrm{m}^{2}\right)$ intervals because of increased thermal conductivity at depth. Harris et al. (2011) modified the shallow heat flow by correcting for the bathymetry relief and rapid sedimentation in the Kumano Basin during 1 to $2 \mathrm{Ma}$, resulting in $57 \mathrm{~mW} / \mathrm{m}^{2}$. This value is in excellent agreement with the heat flow at 900 mbsf determined from LTBMS. The results imply that the rapid sedimentation had little effect on the deeper interval around $900 \mathrm{mbsf}$, at least in terms of temperature 


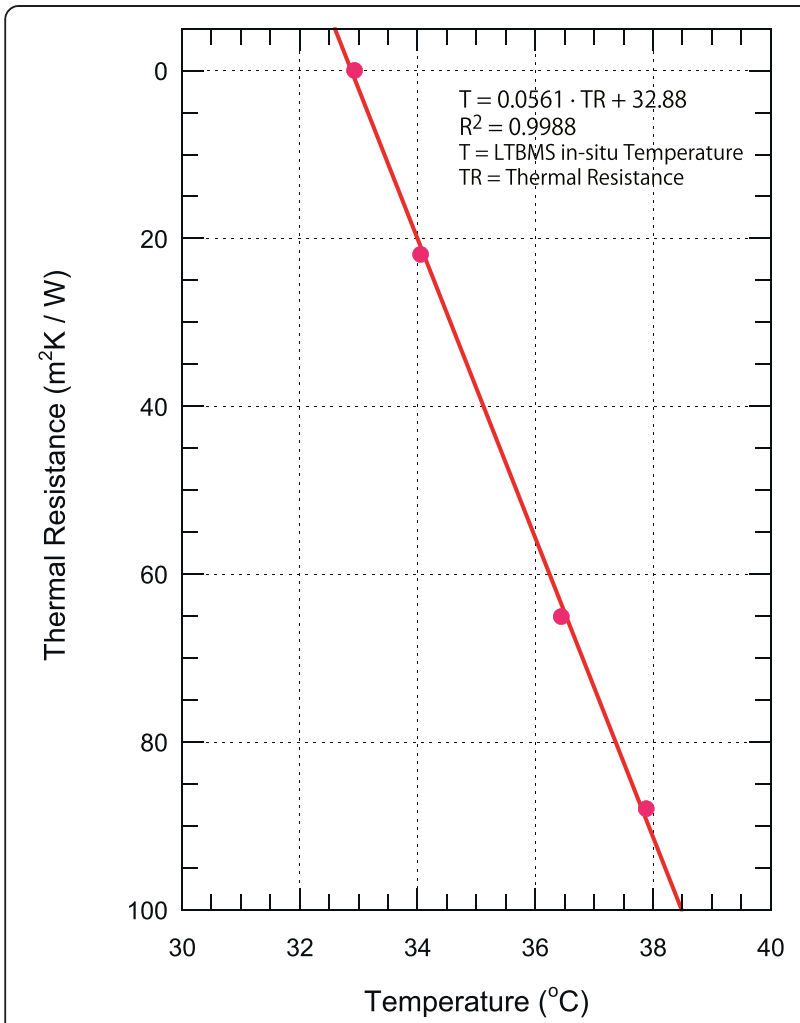

Figure 6 Temperature versus thermal resistance plot. Based on the Bullard equation, the slope of this plot corresponds to heat flow in this depth range. The obtained heat flow is $56.1 \mathrm{~mW} / \mathrm{m}^{2}$.

gradient. In addition, the results also indicate the importance of the bathymetry relief and sedimentation correction by Harris et al. (2011).

\section{Temperature estimation below 900 mbsf Governing equation}

A 1-D, steady-state thermal conduction model was applied to extrapolate the temperature below 900 mbsf:

$$
\frac{\partial}{\partial z}\left(k(z) \frac{\partial T}{\partial z}\right)+A(z)=0
$$

where $A(z)$ includes both the radioactive and frictional heat production. By using two boundary conditions at 900 mbsf (top boundary) as mentioned above, i.e., $37.9^{\circ} \mathrm{C}$ and $56 \mathrm{~mW} / \mathrm{m}^{2}$, Equation 2 can be solved by downward integration.

The thermal conductivity and internal heat source $A(z)$ were inferred from currently available data, as described below.

\section{Radioactive heat production}

Since the old accretionary sediments are composed of pelagic claystone deposited in the Philippine Sea plate and terrigenous silt to sandstone accumulated in the past trench, concentrations of radioactive elements (K, U, Th) in the old accretionary sediments are higher than those in typical basaltic oceanic crust (e.g., Yamaguchi et al. 2001). Therefore, radioactive heat production in the accretionary prism sediments is not negligible in estimating the temperature profile. Since Harris et al. (2011) assumed that the range of radioactive heat production $(R)$ of the accretionary prism sediments is 1.9 to $2.4 \mu \mathrm{W} / \mathrm{m}^{3}$, both values of $R$ were applied in this study as lower and upper limits of radioactive heat production, respectively.

\section{Frictional heat generation}

The frictional heat energy dissipated during an earthquake is given as a product of the shear stress and the slip distance along the fault. Thus, the heat energy, if it is averaged over geological time, does not depend on whether the slip distribution in time is continuous or episodic. In this context, we can assume that frictional heat is continuously generated along the fault with a slip velocity similar to the plate convergence rate.

Assuming a Coulomb failure theory, the frictional heating rate $Q_{f}$ is given as

$$
Q_{f}=\tau \nu=\mu^{\prime} \sigma_{n} \nu,
$$

where $\tau$ is the shear stress during slip, $v$ is the plate convergence rate, $\mu$ is the apparent frictional coefficient of the fault plane, and $\sigma_{n}$ is the normal stress across the fault.

The apparent frictional coefficient is set at 0.05 at both fault zones (Hamamoto et al. 2011). Because of the shallow dip angle of both faults, the normal stress is assumed to be equal to the overburden or lithostatic pressure estimated from the assumed bulk density value of $2,300 \mathrm{~kg} / \mathrm{m}^{3}$ (Kinoshita et al. 2013). Since Hamamoto et al. (2011) reported that the variation in the Philippine Sea plate convergence rate is not critical in estimating the thermal structure of the Nankai subduction zone, we also assumed $4.0 \mathrm{~cm} /$ year for the Philippine Sea plate convergence rate. The frictional heat flow across the megasplay and plate boundary fault below Site C0002 was estimated at approximately 8 $\mathrm{mW} / \mathrm{m}^{2}$ and approximately $10 \mathrm{~mW} / \mathrm{m}^{2}$, respectively.

\section{Thermal conductivity}

Since core samples below 1,150 mbsf were available, we constructed a thermal conductivity model using available borehole information down to the fault zone.

Thermal conductivity of a sediment formation $\left(k_{b}\right)$ is empirically best described using the geometrical mean model as a function of porosity $(\phi)$ and grain thermal conductivity $k_{g}$ (e.g., Brigaud and Vasseur 1989):

$$
k_{b}=k_{g}^{(1-\phi)} \cdot k_{w}{ }^{\phi},
$$

where $k_{w}$ is the thermal conductivity of pore water $(0.6$ $\mathrm{W} / \mathrm{K} / \mathrm{m})$. 
Porosity Porosity is inferred from LWD resistivity or from density or thermal neutron logs or is measured on core samples or cuttings, designated as moisture and density (MAD) porosity (Blum 1997; Expedition 314 Scientists 2009; Moore et al. 2013; Expedition 315 Scientists, 2009).

The LWD data were acquired during Expeditions 314 and 338 (Table 1; Expedition 314 Scientists 2009; Moore et al. 2013). During Expedition 314, both neutron porosity and density-derived porosity were logged, although neither was carried out during Expedition 338. Thus, we used the porosity derived from bit resistivity, which was logged during both expeditions (Figure 7). Data processing for calculation of porosity from the LWD resistivity has been described in detail by Expedition 314 Scientists (2009).

Generally, all porosity data had a similar decreasing trend with increasing depth (Figure 7A). However, between 200 and 700 mbsf, the resistivity-derived porosity was notably lower than that in other logs or MAD porosity. The three-dimensional (3-D) seismic reflection volume image identified clear BSRs at $400 \mathrm{mbsf}$ around Site
C0002 (Moore et al. 2009; Kinoshita et al. 2011). An abundance of methane hydrate was inferred from the anomaly in chemical compositions of interstitial water, which has lower salinity than in that at other depths, in core samples taken between 200 and 400 mbsf (Moore et al. 2013). Expedition 314 Scientists (2009) attributed this apparent decrease in porosity to the resistivity difference between hydrate-filled pore space and that filled with free gas. Thus, we excluded resistivity porosity data at this depth interval and instead adopted the MAD porosity data.

The porosity in shallow sediments exponentially decreases with depth due to dewatering by gravitational and/or regional stress-induced compaction (e.g., Athy 1930; Bahr et al. 2001). The LWD porosity between 900 and 2,005 mbsf was fit to an empirical exponential function (Athy 1930):

$$
\phi(z)=\phi_{0} \exp \left(-\frac{z}{L}\right)
$$

where $z$ is depth (mbsf), $\phi_{0}$ is the porosity on the seafloor, and $L$ is an empirically derived constant. As shown in Figure $7 \mathrm{~B}$, the LWD porosity fit well to Equation 5,
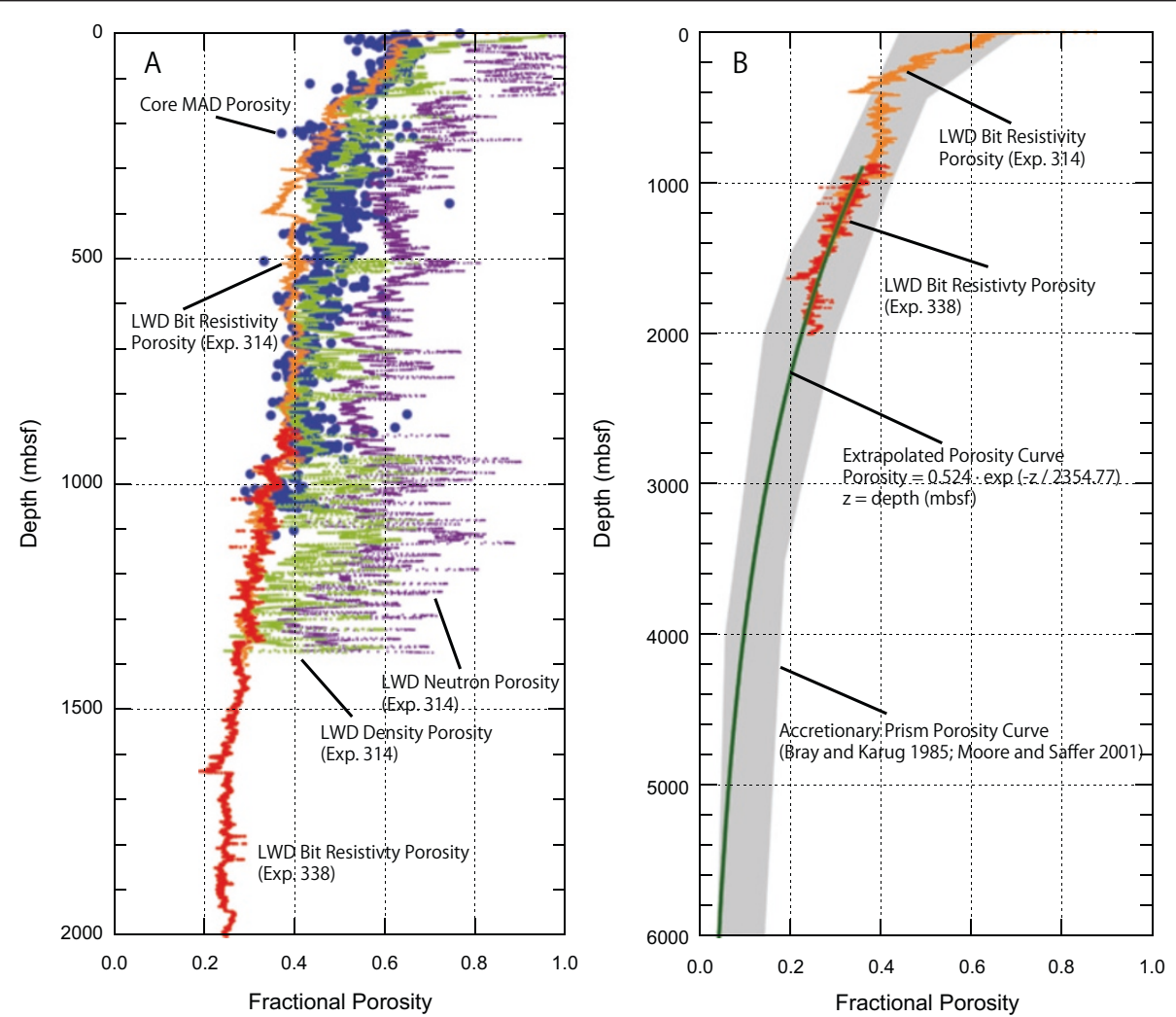

Figure 7 Comparison of porosity data from (A) LWD and laboratory MAD measurement and (B) LWD porosity models with increasing depth. Porosity data derived from the LWD bit resistivity below 900 meters below the sea floor (mbsf) just above unconformity between the Kumano Basin sediments and the old accretionary sediments fit well with the exponential function of Athy's law (Athy 1930) and within the range of accretionary wedges worldwide, which were compiled with core data acquired in Deep Sea Drilling Program (DSDP) and Ocean Drilling Program (ODP) cruises in addition to porosity estimated from seismic data (Bray and Karig 1985; Moore and Saffer 2001). 
and the regression curve was extrapolated to the plate boundary megathrust. This extrapolated porosity curve is within a range of porosity variation with depth in accretionary prisms worldwide (Bray and Karig 1985; Moore and Saffer 2001).

Alternatively, we could use an empirical relationship between $\mathrm{P}$-wave velocity $(\mathrm{Vp})$ and porosity. Han et al. (1986) measured Vp for sedimentary rocks and showed a linear relationship between $\mathrm{Vp}$, porosity, and clay content. Taking the $\mathrm{Vp}$ of approximately $4 \mathrm{~km} / \mathrm{s}$ obtained from seismic surveys (e.g.,Nakanishi et al. 2008), the porosity was estimated at approximately $10 \%$ for $50 \%$ clay (Han et al. 1986) to approximately $0 \%$ for $70 \%$ clay (Kowallis et al. 1984). Although we did not determine the clay abundance below Site C0002, these estimates are in general agreement with resistivity-derived values.
Grain thermal conductivity Figure $8 \mathrm{C}$ shows the grain thermal conductivity estimated at each depth from the best-fit MAD porosity (Equation 5) and the measured thermal conductivity (Figures 8A,B). Most of the grain thermal conductivities at depths of 900 to $1100 \mathrm{mbsf}$ range from $2.5 \mathrm{~W} / \mathrm{K} / \mathrm{m}$ to $3.0 \mathrm{~W} / \mathrm{K} / \mathrm{m}$.

Assuming that lithology does not change with depth, the bulk thermal conductivity can be modeled from these grain conductivities as lower and upper bounds. Using Equations 4 and 5, bulk thermal conductivity values $\left(k_{\mathrm{b}}\right)$ were computed at every $10 \mathrm{~m}$ depth interval from 900 to 7,000 mbsf (Figure 9) and were corrected for in situ temperature in the same manner as that described by Expedition 316 Scientists (2009) and Harris et al. (2011). The lower bound model $\left(k_{\mathrm{g}}=2.5 \mathrm{~W} / \mathrm{K} / \mathrm{m}\right)$ agreed well with the results of Spinelli and Harris (2011; Figure 9).

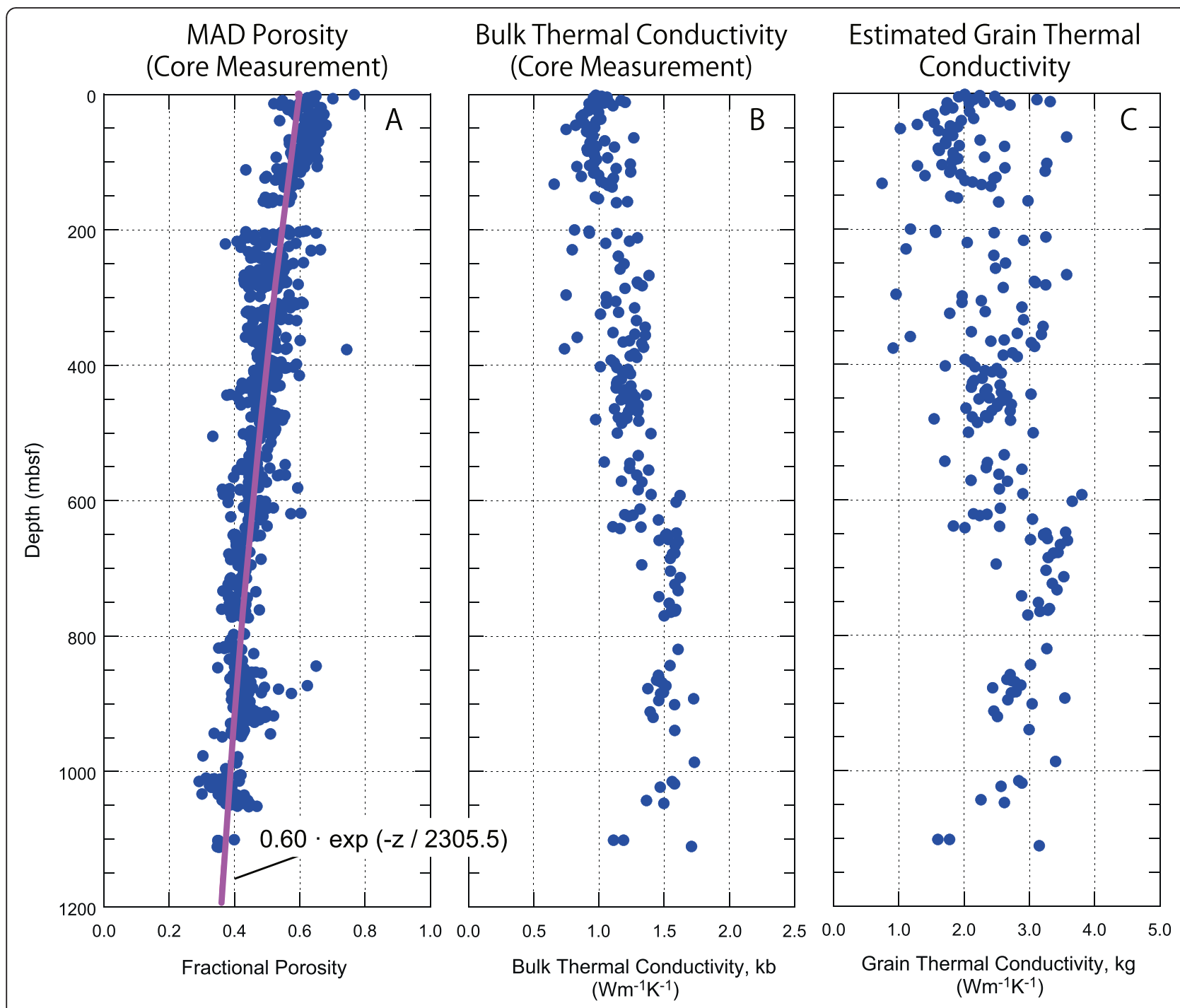

Figure 8 Estimated grain thermal conductivity. (A) Porosity derived from moisture and density (MAD) measurement for core samples. (B) Bulk thermal conductivity measured for core samples. (C) Estimated grain thermal conductivity based on Equation 5. 


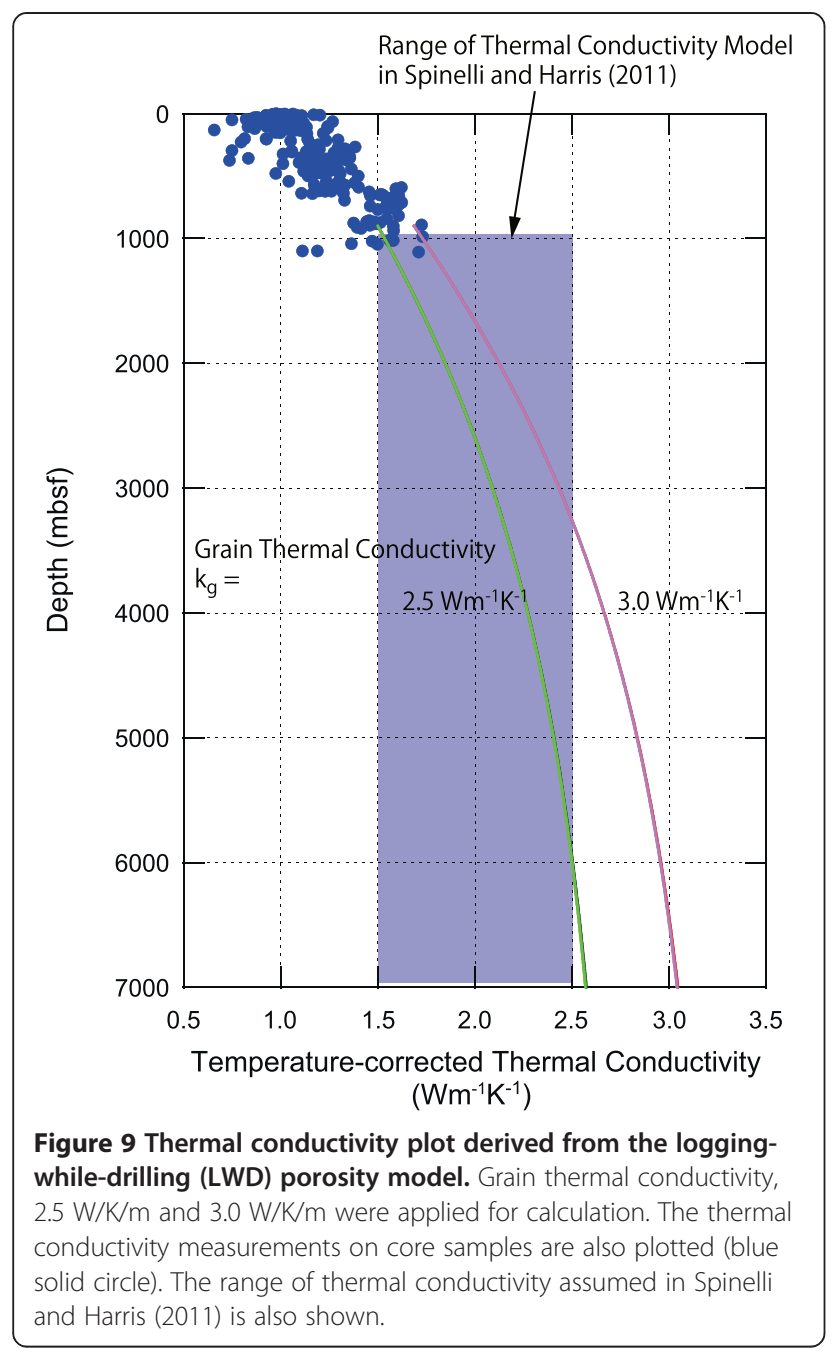

\section{Temperature estimates}

Estimated temperature profiles from 900 to $7,000 \mathrm{mbsf}$ using Equation 2 are shown in Figure 10. The sensitivity of the thermophysical parameters, including grain thermal conductivity, radioactive heat production, and frictional heat, to the temperature at the fault zones, were tested and are shown in Table 3. A comparison between two grain thermal conductivities $\left(k_{\mathrm{g}}=2.5\right.$ and $3.0 \mathrm{~W} / \mathrm{K} / \mathrm{m}$, or $20 \%$ deviation) yielded a megasplay temperature deviation of 14 to $15^{\circ} \mathrm{C}$, or approximately $10 \%$. On the contrary, a comparison of two radiogenic heat production cases $\left(1.9 \mu \mathrm{W} / \mathrm{m}^{3}\right.$ and $2.4 \mu \mathrm{W} / \mathrm{m}^{3}$, or $25 \%$ deviation) yielded a megasplay temperature deviation of $2^{\circ} \mathrm{C}$ or approximately $1.4 \%$. A $50 \%$ deviation in the apparent frictional coefficients $(0.05$ and 0.1$)$ gave less than $0.1 \%$ deviation $\left(0.1^{\circ} \mathrm{C}\right)$ in the megasplay temperature. Thus, the temperature is primarily sensitive to the thermal conductivity uncertainty.

Based on Figure 10 and Table 3, the temperature at 5,200 mbsf (megasplay fault zone) was estimated to be

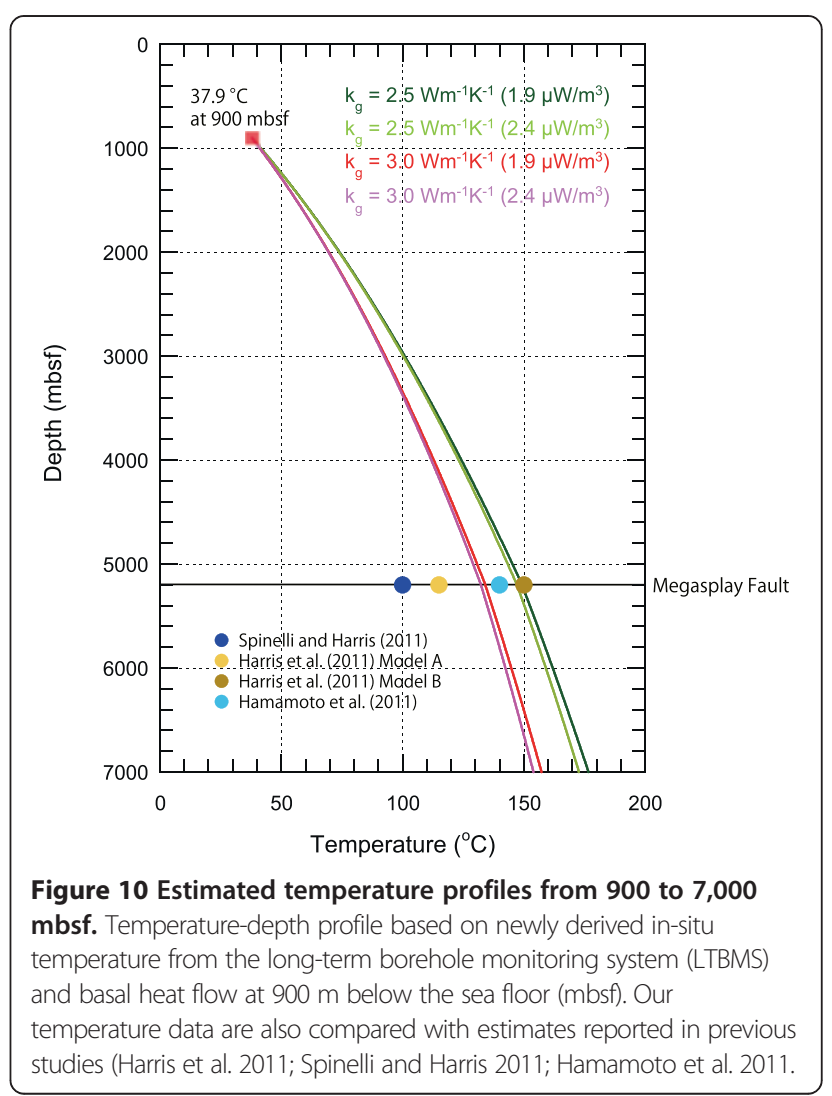

147 to $149^{\circ} \mathrm{C}$ for $k_{\mathrm{g}}=2.5 \mathrm{~W} / \mathrm{K} / \mathrm{m}$ and 132 to $134^{\circ} \mathrm{C}$ for $k_{\mathrm{g}}=3.0 \mathrm{~W} / \mathrm{K} / \mathrm{m}$. In addition, uncertainty of the estimated temperatures was less than $3^{\circ} \mathrm{C}$ at $5,200 \mathrm{mbsf}$ based on the error in the estimated heat flow, as mentioned above.

\section{Results and discussion}

In Figure 10, temperatures estimated in this study are compared with those of previous studies at the depth of the megasplay fault (Harris et al. 2011; Hamamoto et al. 2011; Spinelli and Harris 2011). Our estimates are closer to models by Hamamoto et al. (2011) and model B in Harris et al. (2011). The temperature modeled by Spinelli and Harris (2011) is much lower than that in our model.

Regional heat flow along the Kumano Transect decreases landward from $>100 \mathrm{~mW} / \mathrm{m}^{2}$ on the Nankai Trough to approximately $60 \mathrm{~mW} / \mathrm{m}^{2}$ in the Kumano forearc basin (e.g., Harris et al. 2013). Spinelli and Harris (2011) suggested that the high heat-flow anomaly around the deformation front indicates a fluid flow from the deeper part in the subducting basaltic oceanic crust and results in heat loss and low temperature on the megasplay fault (approximately $100^{\circ} \mathrm{C}$ ). Harris et al. (2013) and Spinelli (2014) also indicated that their numerical model based on this hypothesis effectively explains the surface 
Table 3 Summary of calculated temperature response for each thermal parameter

\begin{tabular}{|c|c|c|c|c|c|c|c|c|}
\hline \multirow{4}{*}{$\begin{array}{l}\text { Depth } \\
\text { (mbsf) }\end{array}$} & \multicolumn{8}{|c|}{ Temperature $\left({ }^{\circ} \mathrm{C}\right)$} \\
\hline & \multicolumn{4}{|c|}{$k_{\mathrm{g}}=2.5(\mathrm{~W} / \mathrm{K} / \mathrm{m})$} & \multicolumn{4}{|c|}{$k_{\mathrm{g}}=3.0(\mathrm{~W} / \mathrm{K} / \mathrm{m})$} \\
\hline & \multicolumn{2}{|c|}{$R=1.9\left(\mu \mathrm{W} / \mathrm{m}^{3}\right)$} & \multicolumn{2}{|c|}{$R=2.4\left(\mu \mathrm{W} / \mathrm{m}^{3}\right)$} & \multicolumn{2}{|c|}{$R=1.9\left(\mu \mathrm{W} / \mathrm{m}^{3}\right)$} & \multicolumn{2}{|c|}{$R=2.4\left(\mu \mathrm{W} / \mathrm{m}^{3}\right)$} \\
\hline & $\mu^{\prime}=0.05$ & $\mu^{\prime}=0.10$ & $\mu^{\prime}=0.05$ & $\mu^{\prime}=0.10$ & $\mu^{\prime}=0.05$ & $\mu^{\prime}=0.10$ & $\mu^{\prime}=0.05$ & $\mu^{\prime}=0.10$ \\
\hline 900 & 37.9 & 37.9 & 37.9 & 37.9 & 37.9 & 37.9 & 37.9 & 37.9 \\
\hline 1,000 & 41.6 & 41.6 & 41.6 & 41.6 & 41.2 & 41.2 & 41.2 & 41.2 \\
\hline 2,000 & 74.0 & 74.0 & 73.8 & 73.8 & 69.7 & 69.7 & 69.5 & 69.5 \\
\hline 3,000 & 100.9 & 100.9 & 100.3 & 100.3 & 92.9 & 92.9 & 92.4 & 92.4 \\
\hline 4,000 & 124.3 & 124.3 & 123.1 & 123.1 & 112.9 & 112.9 & 111.9 & 111.9 \\
\hline 5,000 & 145.3 & 145.3 & 143.4 & 143.4 & 130.8 & 130.8 & 129.1 & 129.1 \\
\hline $5,200^{a}$ & 149.2 & 149.2 & 147.2 & 147.1 & 134.1 & 134.1 & 132.3 & 132.3 \\
\hline 6,000 & 161.9 & 159.3 & 159.1 & 156.5 & 144.9 & 142.6 & 142.4 & 140.2 \\
\hline $7,000^{\mathrm{a}}$ & 176.6 & 170.9 & 172.7 & 166.9 & 157.3 & 152.4 & 154.0 & 149.1 \\
\hline
\end{tabular}

$k_{\mathrm{g}}$ grain thermal conductivity; $R$, radioactive heat production; $\mu^{\prime}$, apparent friction coefficient. ${ }^{a}$ We assume friction heat is generated at 5,200 mbsf (megasplay fault) and 7,000 mbsf (plate boundary fault).

heat flow distribution. Thus, the two-dimensional (2-D) thermal structure model by Spinelli and Harris (2011) would provide a better understanding for the thermal structure in the Nankai subduction zone. However, our 1-D temperature estimation, based on measured in situ temperatures and thermal conductivity values on core samples at 900 mbsf, does not support a temperature lower than $130^{\circ} \mathrm{C}$ at the megasplay fault below Site C0002. We attempted to determine the cause for such discrepancies (up to $40^{\circ} \mathrm{C}$ ) in temperature at the megasplay fault.

The temperature at 5,200 mbsf estimated by Hamamoto et al. (2011), in which the thermal parameters used are almost similar to those used in the present study, is very close to the result of our 1-D temperature estimation (Figure 10). In addition, their thermal model also does not include the influence of the advective cooling in the subducting basaltic oceanic crust. Therefore, we suspect that the disagreement in the estimated megasplay temperature is primarily attributed to the advective cooling in the 2-D system, which can disturb the temperature distribution in the accretionary wedge above the megasplay. Moreover, we consider that the temperatures at the depth of the megasplay fault shown in this study indicate an upper bound to the temperature at that depth.

A future revision of 2-D simulation by including the results of our temperature estimation based on the in situ temperature at $900 \mathrm{mbsf}$ and the heat flow derived from the temperatures, LWD, and the measured thermal conductivity data on the core sample would improve estimates of the overall thermal regime in the Nankai subduction zone. For future study, additional downhole information is important as are more surface heat flow and hydrological data. Further, drilling to the megasplay fault, wireline logging, and installation of a long-term observatory with temperature sensors in the drilled holes should be essential components for future research.

\section{Conclusions}

Based on newly derived in situ temperature data, the temperature profile beneath Site C0002 was investigated. A summary of the investigation is included in the following points:

(1) Intermittently, retrieved LTBMS temperature data were stabilized approximately 2 years after installation, indicating that temperatures at 760 to 900 mbsf recorded in early 2013 were in thermal equilibrium with the formation. In situ temperature at $900 \mathrm{mbsf}$ was accurately determined as $37.9^{\circ} \mathrm{C}$, and the heat flow from the old accretionary sediments below was estimated to be $56 \pm 1 \mathrm{~mW} /$ $\mathrm{m}^{2}$. This value is in excellent agreement with previously determined heat flow for the shallow depth interval after correction for rapid sedimentation in the Kumano Basin. The agreement implies that the rapid sedimentation does not affect the temperature gradient as deep as $900 \mathrm{mbsf}$.

(2)A 1-D, steady-state thermal conduction model was used to extrapolate the temperature down to the plate boundary at 7,000 mbsf at Site C0002. Thermal conductivity was inferred using a geometrical mean model from porosities estimated from LWD resistivity for two assumed grain conductivity values $\left(k_{g}=2.5 \mathrm{~W} / \mathrm{K} / \mathrm{m}\right.$ and $\left.3.0 \mathrm{~W} / \mathrm{K} / \mathrm{m}\right)$. Radioactive heat production in the accreted sediment and the frictional heating at the megasplay and plate boundary faults were considered. The temperatures at the depth of the megasplay fault were estimated to be 147 to $149^{\circ} \mathrm{C}$ for $k_{g}=2.5 \mathrm{~W} / \mathrm{K} / \mathrm{m}$ and 132 to $134^{\circ} \mathrm{C}$ for $k_{g}=3.0 \mathrm{~W} / \mathrm{K} / \mathrm{m}$. 
(3) The temperatures estimated by the 1-D simulation are close to some of the previous estimates (e.g., Hamamoto et al. 2011) but are significantly lower (by approximately $40^{\circ} \mathrm{C}$ ) than those modeled by Spinelli and Harris (2011), who introduced advective heat transport in the subducting basaltic crust in order to produce high heat flow near the deformation front. These results indicate that further revision for the 2-D numerical models is needed and that quantitative re-evaluation of the influence of advective cooling in the basaltic oceanic crust is essential.

(4) For better understanding of the characteristics around the Nankai seismogenic zone, it is important to drill to the megasplay fault to obtain thermal properties to ultimately measure in situ temperature with a borehole observatory.

\section{Competing interests}

The authors declare that they have no competing interests.

\section{Authors' contributions}

TS conducted the analysis of in situ temperature, LWD, and core measurement data and also conducted scientific interpretation for results of the data analysis. MK conducted the analysis of in situ temperature, LWD, and core measurement data and also conducted scientific interpretation for results of the data analysis. EA and TK are PIs of the LTBMS project and developed and implemented sensors in the LTBMS. MK and YN are PIs of the LTBMS project and conducted integration of the LTBMS system. YK, YS, and MKT are logging staff scientists on board Chikyu and processed LWD data. All authors read and approved the final manuscript.

\section{Acknowledgments}

This research used samples and data provided by the Integrated Ocean Drilling Program (IODP). We thank co-chief scientists and shipboard science parties for usage of measurement data acquired during the past NanTroSEIZE expeditions. We also appreciate the ship and drilling personnel, staff, and technicians aboard the DN Chikyu for their work. We thank R.N. Harris, an anonymous reviewer, and associate editors for providing productive comments that helped to improve this manuscript.

\section{Author details \\ ${ }^{1}$ Center for Deep Earth Exploration, Japan Agency for Marine-Earth Science and Technology, 3173-25 Showa-machi, Kanazawa-ku, Yokohama 236-0001, Japan. ${ }^{2}$ Kochi Institute for Core Sample Research, Japan Agency for Marine-Earth Science and Technology, 200 Monobe B, Nankoku, Kochi 783-8502, Japan. ${ }^{3}$ Earthquake and Tsunami Research Project for Disaster Prevention, Japan Agency for Marine-Earth Science and Technology, 2-15, Natsushima-cho, Yokosuka 237-0061, Japan.}

Received: 7 February 2014 Accepted: 21 August 2014 Published: 4 September 2014

\section{References}

Ashi J, Lallemant S, Masago H, Expedition 315 Scientists (2009) Expedition 315 Summary. In: Expedition 314/315/316 Scientists (ed) Proc. IODP 314/315/316. Integrated Ocean Drilling Program Management International, Inc, Washington, D.C. ISBN doi:10.2204/odp.proc.314315316.121.2009

Athy LF (1930) Density, porosity, and compaction of sedimentary rocks. Amer Ass Petrol Geol Bull J Internat 110:577-590

Bahr DB, Hutton EWH, Syvitski JPM, Prason LF (2001) Exponential approximations to compacted sediment porosity profiles. Comp Geosci 27:691-700

Blum P (1997) Physical properties handbook. ODP Technical Note 26: doi:10.2973/odp.tn.26.1997

Bray CJ, Karig DE (1985) Porosity of sediments in accretionary prisms and some implications for dewatering processes: J Geophys Res 90:768-778
Brigaud F, Vasseur G (1989) Mineralogy, porosity and fluid control on thermal conductivity of sedimentary rocks. Geophys J 98:525-542

Bullard EC (1939) Heat flow in South Africa. Proc R Soc London, Ser A 173:474-502

Expedition 314 Scientists (2009) Expedition 314 Site C0002. In: Expedition 314/315/316 Scientists (ed) Proc. IODP 314/315/316. Integrated Ocean Drilling Program Management International, Inc, Washington, D.C, doi:10.2204/iodp.proc.314315316.114.2009

Expedition 315 Scientists (2009) Expedition 315 Site C0002. In: Kinoshita M, Tobin H, Ashi J, Kimura G, Lallemant S, Screaton EJ, Curewitz D, Masago H, Moe KT (eds) Expedition 314/315/316 Scientists (eds) Proc. IODP 314/315/316. Integrated Ocean Drilling Program Management International, Inc, Washington, D.C, doi:10.2204/iodp.proc.314315316.124.2009

Expedition 316 Scientists (2009) Expedition 316 Methods. In: Kinoshita M, Tobin H, Ashi J, Kimura G, Lallemant S, Screaton EJ, Curewitz D, Masago H, Moe KT (eds) Expedition 314/315/316 Scientists (eds) Proc. IODP 314/315/316. Integrated Ocean Drilling Program Management International, Inc, Washington, D.C, doi:10.2204/iodp.proc.314315316.132.2009

Expedition 332 Scientists (2011a) Methods. In: Kopf A, Araki E, Toczko S (eds) Expedition 332 Scientists (eds) Proc. IODP 332. Integrated Ocean Drilling Program Management International, Inc, Tokyo, doi:10.2204/iodp. proc.332.102.2011

Expedition 332 Scientists (2011b) Site C0002. In: Kopf A, Araki E, Toczko S (eds) Expedition 332 Scientists (eds) Proc. IODP 332. Integrated Ocean Drilling Program Management International, Inc, Tokyo, doi:10.2204/iodp. proc.332.104.2011

Hamamoto H, Yamano M, Goto S, Kinoshita M, Fujino K, Wang K (2011) Heat flow distribution and thermal structure of the Nankai Subduction zone off the Kii Peninsula. Geochem Geophys Geosys 12:, doi:10.1029/2011GC003623

Han D, Nur A, Morgan D (1986) Effects of porosity and clay content on wave velocities in sandstones. Geophysics 51:2093-2107

Harris RN, Schmidt-Schierhorn F, Spinelli G (2011) Heat flow along the NanTroSEIZE trancect: results from IODP Expedition 315 and 316 offshore the Kii Peninsula, Japan. Geochem Geophys Geosys 12:, doi:10.1029/ 2011GC003593

Harris RN, Yamano M, Kinoshita M, Spinelli G, Hamamoto H, Ashi J (2013) A Synthesis of heat flow determinations and thermal modeling along the Nankai Trough, Japan. Jour Geophys Res 118:2687-2702, doi:10.1002/ jgrb.50230

Heesemann M, Villinger H, Fisher AT, Tréhu AM, White S (2006) Data report: testing and deployment of the new APCT-3 tool to determine in situ temperatures while piston coring. In: Riedel M, Collett TS, Malone MJ (eds) Expedition 311 Scientists (eds) Proc. IODP 311. Integrated Ocean Drilling Program Management International, Inc, Washington, D.C, doi:10.2204/iodp. proc.311.108.2006

Henry P, Kanamatsu T, Moe KT, Expedition 333 Scientists (2012) Proc. IODP 333. Integrated Ocean Drilling Program Management International, Inc, Tokyo, doi:10.2204/iodp.proc.333.2012

Hyndman RD, Wang K, Yamano M (1995) Thermal constraints on the seismogenic portion of the southwestern Japan subduction thrust. J Geophys Res 100(15):15373-15392, doi:10.1029/2011 JB008840

Kimura T, Araki E, Takayama H, Kitada K, Kinoshita M, Namba Y, Kyo M (2013) Development and performance tests of a sensor suite for a long-term borehole monitoring system in seafloor settings in the Nankai Trough. Japan IEEE J Ocean Engineer 38(2):383-395, doi:10.1109/JOE.2012.2225293

Kinoshita M, Tobin H, Ashi J, Kimura G, Lallemant S, Screaton EJ, Curewitz D, Masago H, Moe KT, Expedition 314/315/316 Scientists (2009) Proc. IODP 314/ 315/316. Integrated Ocean Drilling Program Management International, Inc, Washington, D.C, doi:10.2204/iodp.proc.314315316.2009

Kinoshita M, Moore GF, Kido YN (2011) Heat flow estimated from BSR and IODP borehole data: Implication of recent uplift and erosion of the imbricate thrust zone in the Nankai Trough off Kumano. Geochem Geophys Geosyst 12:Q0AD18, doi:10.1029/2011GC003609

Kinoshita M, Sugihara T, Araki E, Kimura T, Kyo M, Namba Y, Kido Y, Sanada Y, Moe K (2013) Revised Temperature At The updip limit of locked portion of Nankai megasplay, inferred from IODP Site C0002 Temperature Observatory. In: Abstract T33F-07 Presented at 2013 Fall Meeting. AGU, San Francisco, Calif, December 9-13

Kitada K, Araki E, Kimura T, Kinoshita M, Kopf A, Saffer D (2013) Long-term monitoring at C0002 Seafloor Borehole in Nankai Trough Seismogenic Zone. Proceedings of Underwater Technology Symposium 2013 IEEE International, doi:10.1109/UT.2013.6519882 
Kopf A, Araki E, Toczko S, Expedition 332 Scientists (2011) Proc. IODP, 332 Integrated Ocean Drilling Program Management International, Inc, Tokyo, doi:10.2204/iodp.proc.332.2011

Kowallis BJ, Jones LEA, Wang HP (1984) Velocity-porosity-clay content systematic of poorly consolidated sandstones. J Geophys Res 89:10355-10364

Moore JC, Saffer D (2001) Updip limit of the seismogenic zone beneath the accretionary prism of southwest Japan: an effect of diagenetic to low-grade metamorphic process and increasing effective stress. Geology 29:183-186, doi:10.1130/0091-7613(2001)029<0183:ULOTSZ>2.0.CO;2

Moore GF, Park JO, Bangs NL, Gulick SP, Tobin HJ, Nakamura Y, Sato S, Tsuji T, Yoro T, Tanaka H, Uraki S, Kido Y, Sanada Y, Kuramoto S, Taira A (2009) Structural and seismic stratigraphic framework of the NanTroSEIZE Stage 1 transect. In: Kinoshita M, Tobin H, Ashi J, Kimura G, Lallemant S, Screaton EJ, Curewitz D, Masago H, Moe KT (eds) Expedition 314/315/316 Scientists, Proc. IODP 314/315/316. Integrated Ocean Drilling Program Management International, Inc, Washington, D.C, doi:10.2204/iodp.proc.314315316.102.2009

Moore G, Kanagawa K, Strasser M, Dugan B, Maeda L, Toczko S, Expedition 338 Scientists (2013) NanTroSElZE Stage 3: NanTroSEIZE plate boundary deep riser 2. IODP Prel Rept 338:, doi:10.2204/iodp.pr.338.2013

Nakanishi A, Kodaira S, Miura S, Ito A, Sato T, Park JO, Kido Y, Kaneda Y (2008) Detailed structural image around splay-fault branching in the Nankai subduction seismogenic zone: results from a high-density ocean bottom seismic survey. J Geophys Res 113, B03105, doi:10.1029/2007JB004974

Park J, Kodaira S (2012) Seismic reflection and bathymetric evidences for the Nankai earthquake rupture across a stable segment-boundary. Earth Planets Space 64:299-303

Park JO, Tsuru T, Kodaira S, Cummins PR, Kaneda Y (2002) Splay fault branching along the Nankai subduction zone. Science 297(5584):1157-1160, doi:10.1126/science.1074111

Saffer D, McNeill L, Byrne T, Araki E, Toczko S, Eguchi N, Takahasshi K, Expedition 319 Scientists (2010) Proc. IODP 319. Integrated Ocean Drilling Program Management International, Inc, Tokyo, doi:10.2204/iodp.proc.319.2010

Saito S, Underwood MB, Kubo Y, Expedition 322 Scientists (2010) Proc. IODP 322. Integrated Ocean Drilling Program Management International, Inc, Tokyo, doi:10.2204/iodp.proc.322.2010

Spinelli G (2014) Long-distance fluid and heat transport in the oceanic crust entering the Nankai subduction zone, NanTroSElzE transect, Earth Planet. Sci Lett 389:86-94, doi:10.1016/j.epsl.2013.12.013

Spinelli G, Harris RN (2011) Thermal effects of hydrothermal circulation and seamount subduction: temperature in the Nankai Trough Seismogenic Zone Experiment transect. Japan Geochem Geophys Geosys 12: doi:10.1029/2011GC003727

Steinhart JS, Hart SR (1968) Calibration curves for thermistors. Deep-Sea Res 15:497-503, doi:10.1016/0011-7471(68)90057-0

Tobin H, Kinoshita M (2006) NanTroSElZE: The IODP Nankai Trough seismogenic zone experiment. Sci Drill 2:23-27, doi:10.2204/iodp.sd.2.06.2006

Yamaguchi IT, Yamano M, Nagao T, Goto S (2001) Distribution of radioactive heat production around an active fault and in accretionary prism of southwest Japan. Phys Earth Planet Inter 126:269-277, doi:10.1016/s0031-9201(01)00260-6

doi:10.1186/1880-5981-66-107

Cite this article as: Sugihara et al:: Re-evaluation of temperature at the updip limit of locked portion of Nankai megasplay inferred from IODP Site $\mathrm{C0002}$ temperature observatory. Earth, Planets and Space 2014 66:107.

\section{Submit your manuscript to a SpringerOpen ${ }^{\circ}$ journal and benefit from:}

- Convenient online submission

- Rigorous peer review

- Immediate publication on acceptance

- Open access: articles freely available online

- High visibility within the field

- Retaining the copyright to your article

Submit your next manuscript at $\gg$ springeropen.com 